\title{
RECYCLING OF COAL GANGUE TO PREPARE LOW DENSITY CERAMIC PROPPANTS FOR COAL BED METHANE WELLS
}

\author{
${ }^{\#}$ JIANYING HAO*, YUNFENG GAO*, XIANJUN LI**, PINBO BAI***, "YUMING TIAN* \\ *Institute of Materials Science and Engineering, Taiyuan University of Science and Technology, Taiyuan 030024, PR China \\ **Department of Civil Engineering, Shanxi University, Taiyuan 030013, PR China \\ ***Changqing Fracturing Proppant Co. Ltd, Yangquan 045000, PR China \\ \#E-mail: jianyinghao@tyust.edu.cn, tianyming@163.com
}

Submitted December 6, 2018; accepted April 25, 2019

\begin{abstract}
Keywords: Ceramic proppants, Sintering, Low density, Coal bed methane well, Coal gangue, Mullite, Cristobalite
Low density ceramic proppants for coal bed methane wells were successfully prepared using flint clay and solid waste coal gangue as raw materials. The addition of coal gangue greatly reduced the preparation cost. The phase composition and morphology of the proppants were examined by X-ray diffraction (XRD) and scanning electron microscopy (SEM). The results showed that the main crystal phases were rod-shaped mullite and granular cristobalite. Furthermore, the suitable amount of coal gangue added was $30-40 \mathrm{wt} . \%$. Proppants prepared with $30 \mathrm{wt} . \%$ and $40 \mathrm{wt} . \%$ coal gangue and sintered

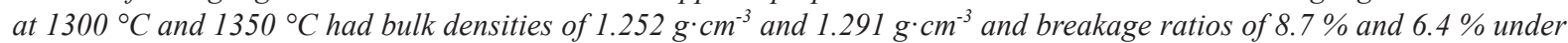
$35 \mathrm{MPa}$ closed pressure, respectively, while for those sintered at $1400^{\circ} \mathrm{C}$, the breakage ratio was $8.9 \%$ under $52 \mathrm{MPa}$ closed pressure.
\end{abstract}

\section{INTRODUCTION}

Proppants are the hard solid particles, such as quartz sands or ceramic particles, that prop the fractures in the hydraulic fracturing process that is used in the petroleum and gas wells and coal bed methane wells. The addition of proppants is indispensable in order to keep the fracture open so that the hydrocarbon production from the petroleum and gas wells and coal bed methane wells can be significantly enhanced [1-4]. Therefore, proppants are of extreme importance as they provide the long-term permeability of the fracture $[5,6]$.

Since the first fracturing operation was done with silica sand proppant in 1947, many materials have been used as proppants, including walnut shells, natural sand, glass, resin coated sand, sintered bauxite and kaolin, and fused zirconia [7]. Even now, sands and ceramic proppants are the two most common proppants in fracturing processes $[1,8]$. Quartz sands are traditionally used owing to their low cost. However, quartz sands reduce the permeability of fracture due to their low strength and poor sphericity $[8,9]$. By contrast, ceramic proppants have many advantages, such as high sphericity and roundness, high strength and hardness, high melting temperature and good chemical inertness in corrosive environments $[10,11]$. Consequently, ceramic proppants are widely used in the deep oil wells. Furthermore, the low density of ceramic proppants allows them to be dragged by the fracture liquid with efficiency and prevents their accumulation in the first part of the fracture [12], whereas high-density proppants can pose severe problems in transport and placement [13]. This indicates that the development of low-density ceramic proppants with better performance is urgently required.

Currently, ceramic proppants available in the market are mainly prepared by bauxite or pure alumina, inevitably increasing the density of the proppants owing to the high alumina content of bauxite [14]. Moreover, these raw materials are expensive due to over-exploitation. Flint clay is a natural ore with rich resource in China and its main composition is $\mathrm{Al}_{2} \mathrm{O}_{3}$ and $\mathrm{SiO}_{2}$. The use of calcined flint clay instead of bauxite to prepare ceramic proppants can reduce the density of proppants due to the lower alumina content. Coal gangue is a hazardous by-product of the coal mining industry, and the average production of coal gangue is about $10-15 \%$ of raw coal production [15]. The main composition of coal gangue is also $\mathrm{SiO}_{2}$ and $\mathrm{Al}_{2} \mathrm{O}_{3}$. The properties of ceramic proppants obtained by flint clay and coal gangue should be in some respects worse than those prepared by bauxite, but neverthless these proppants should be suitable for coal bed methane wells and shallow oil wells.

In the present work, low-density ceramic proppants were prepared by sintering, using calcined flint clay and solid waste coal gangue as raw materials. The effects of the addition of coal gangue on the properties of ceramic proppants were systematically investigated. The maximum addition of coal gangue and corresponding sintering temperature were also determined. 


\section{EXPERIMENTAL}

Raw materials

Calcined flint clay and solid waste coal gangue were obtained from the Yangquan area in Shanxi Province, China. The chemical composition of calcined flint clay and coal gangue were measured according to the Chinese Nonferrous Metals Industry Standard (YS/T 575-2007) and National Standard of PRC (GB/T 27974-2011), respectively. The test results are shown in Table 1. For thermogravimetry (TGA) of the raw materials, a TGA/ DSC 3+ (Metter Toledo, Switzerland) was used and carried out between $30{ }^{\circ} \mathrm{C}$ and $1300{ }^{\circ} \mathrm{C}$ in Ar with a rate of heating at $10^{\circ} \mathrm{C}$ per minute. The results are displayed in Figure 1a, b.

Table 1. Chemical composition of calcined flint clay and coal gangue (wt. \%).

\begin{tabular}{lcccccc}
\hline & $\mathrm{Al}_{2} \mathrm{O}_{3}$ & $\mathrm{SiO}_{2}$ & $\mathrm{Fe}_{2} \mathrm{O}_{3}$ & $\mathrm{TiO}_{2}$ & $\mathrm{CaO}$ & L.O.I \\
\hline Calcined flint clay & 45.58 & 37.82 & 1.13 & 2.61 & 0.47 & 12.39 \\
Coal gangue & 36.29 & 45.75 & 3.29 & 1.02 & 0.32 & 13.33 \\
\hline
\end{tabular}

\section{Preparation of proppants}

The proppants were prepared by pelleting, drying, screening and sintering. The raw material mixture ratios for the different samples are shown in Table 2. First, a certain proportion of calcined flint clay and coal gangue was stirred for $2 \mathrm{~min}$ in a strong mixing machine (R02, Eirich Co. Ltd, Germany) and subsequently spherical green bodies were formed with water. Second, the green bodies were dried at $90^{\circ} \mathrm{C}$ for $2 \mathrm{~h}$ in a drying box (DH101-2BS, Tianjin Central Experiment Furnace Co. Ltd, China), and then the dried bodies were passed through a set of 20/40 mesh sieves (aperture size $0.85-0.43 \mathrm{~mm}$ ). Third, the 20/40 mesh green particles were sintered in a high temperature box-type sintering furnace (KBF1700, Nanjing Bo Yun Tong Instrument Technology Co. Ltd, China) at certain temperature for $2 \mathrm{~h}$ in air with a heating rate of $5{ }^{\circ} \mathrm{C} \cdot \mathrm{min}^{-1}$. Finally, the cooled proppants were passed through the 20/40 mesh sieves.

Table 2. Raw material mixture ratios of the samples prepared (wt. \%).

\begin{tabular}{llllll}
\hline Samples & C1 & C2 & C3 & C4 & C5 \\
\hline Calcined flint clay & 90 & 80 & 70 & 60 & 50 \\
Coal gangue & 10 & 20 & 30 & 40 & 50 \\
\hline
\end{tabular}

\section{Characterization}

Thermogravimetry (TG) and differential scanning calorimetry (DSC) was carried out between $30{ }^{\circ} \mathrm{C}$ to $1300{ }^{\circ} \mathrm{C}$ in Ar with a heating rate of $10{ }^{\circ} \mathrm{C}$ per minute, using a TGA/DSC 3+ (Metter Toledo, Switzerland). According to the Chinese Petroleum and Gas Industry
Standard (SY/T5108-2014), bulk density and apparent density were measured by a calibrated density bottle (pyconometer), and the breakage ratio was calculated by the formula: $\eta=\omega_{c} / w_{0}{ }^{\prime} 100 \%$, where $\omega_{c}$ and $w_{0}$ were the weights of crushed specimens after and before testing, respectively. The phase composition of the proppants was identified by X-ray diffracion / XRD (X'Pert PRO; Philips Co. Ltd, Holland), utilizing Ni-filtered $\mathrm{Cu} \mathrm{K} \alpha$ radiation (40 $\mathrm{kV}$ voltage). The microstructure was examined by field emission scanning electron microscopy / SEM (FESEM, S-4800; Hitachi, Japan) operated at $10 \mathrm{kV}$ voltage.

\section{RESULTS AND DISCUSSION}

The TG and DSC curves for the raw materials are displayed in Figure 1. The DSC curve of calcined flint clay (Figure 1a) shows an endothermic peak at $515{ }^{\circ} \mathrm{C}$ and an exothermic peak at $990{ }^{\circ} \mathrm{C}$. The endothermic peak is caused by the dehydroxylation of donbassite and kaolinite contained in the flint clay. Correspondingly, in the TG curve in the temperature range $400-700{ }^{\circ} \mathrm{C}$ there

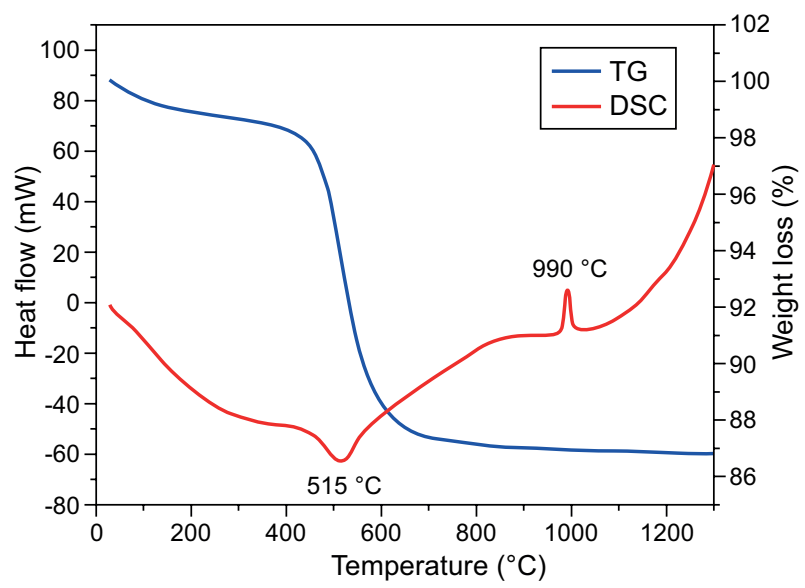

a)

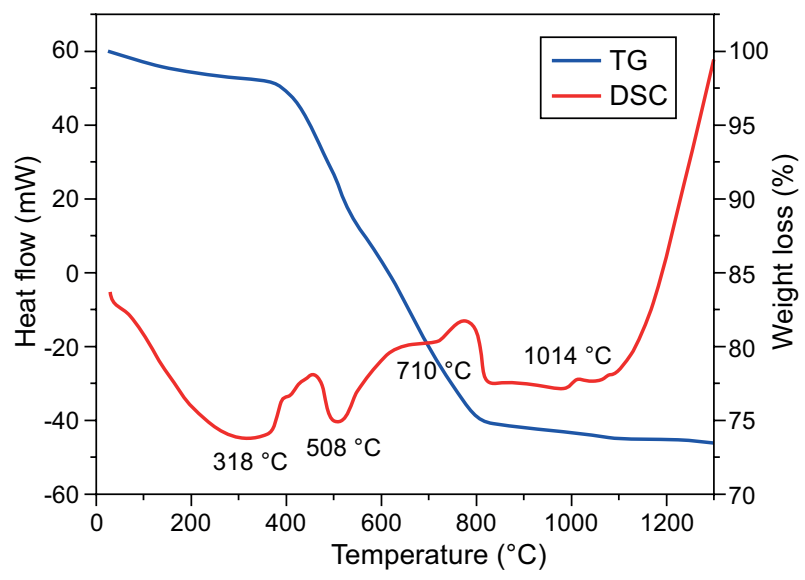

b)

Figure 1. DSC and TG curves of: a) calcined flint clay and b) coal gangue. 
is indication of a mass loss of $10.54 \%$. The exothermic peak at $990{ }^{\circ} \mathrm{C}$ corresponds to the transformation of amorphous $\mathrm{SiO}_{2}$ into cristobalite. In Figure 1b, three endothermic peaks and an exothermic peak are observed on the coal gangue DSC curve. The first endothermic peak at $200-400{ }^{\circ} \mathrm{C}$ was due to the removal of crystal water, which is accompanied by a mass loss of $2.5 \%$ at $200-400{ }^{\circ} \mathrm{C}$ in the TG curve. The second endothermic peak at $450-600{ }^{\circ} \mathrm{C}$ and the third small endothermic peak at $650-780{ }^{\circ} \mathrm{C}$ are caused by the dehydroxylation of kaolinite and muscovite contained in the coal gangue. The mass loss in these two intervals was $11.8 \%$ and $7 \%$, respectively, in the TG curve. The small exothermic peak at $1014{ }^{\circ} \mathrm{C}$ corresponds again to a crystallization phenomenon, that is, the crystllization of cristobalite from the amorphous phase.

The bulk density and apparent density of the proppants sintered at different temperatures are shown in Figure $2 \mathrm{a}$ and $2 \mathrm{~b}$. As seen in Figure 2a, the bulk density increased in most cases as the sintering temperature increased, only that of samples $\mathrm{C} 1$ and $\mathrm{C} 2$ exhibited a slight decrease for sintering temperatures above $1400{ }^{\circ} \mathrm{C}$. The bulk densities of $\mathrm{C} 1$ and $\mathrm{C} 2$ sintered at

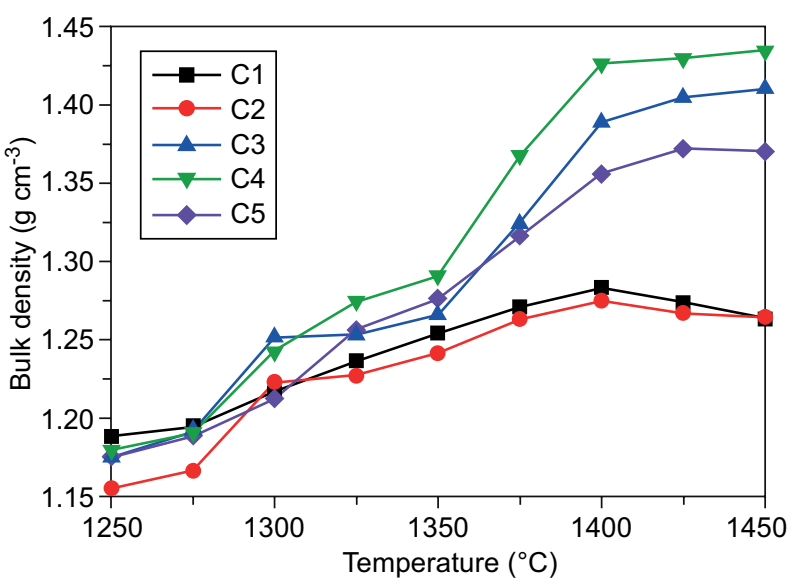

a)

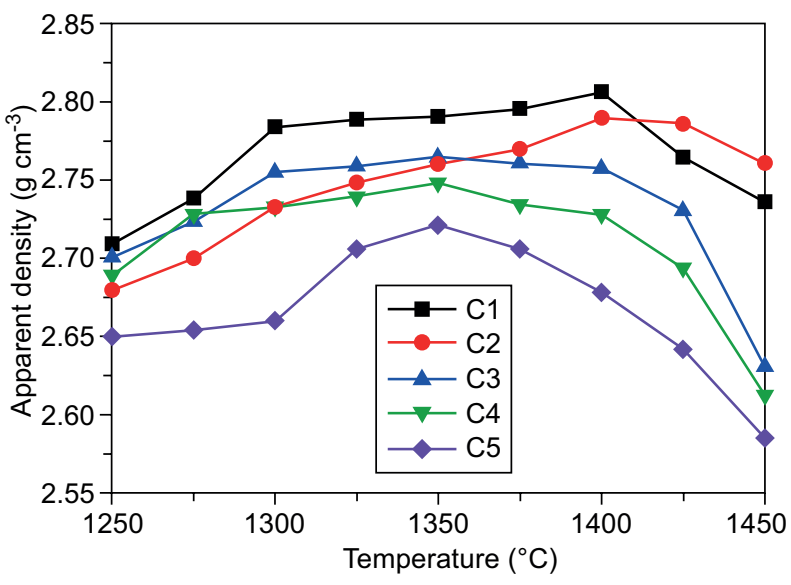

b)

Figure 2. Bulk density (a) and apparent density (b) of the proppants. different temperatures were lower than $1.3 \mathrm{~g} \cdot \mathrm{cm}^{-3}$ and reached maxima of $1.284 \mathrm{~g} \cdot \mathrm{cm}^{-3}$ and $1.275 \mathrm{~g} \cdot \mathrm{cm}^{-3}$, respectively, for a sintering temperature of $1400{ }^{\circ} \mathrm{C}$. The bulk density of $\mathrm{C} 2$ was clearly lower than that of $\mathrm{C} 1$, which indicated that adding a small amount of gangue could reduce the density of the proppants. However, when more coal gangue is added ( $\mathrm{C} 3$ and $\mathrm{C} 4)$, the bulk density for low sintering temperature increased, mainly for sintering temperatures above $1350{ }^{\circ} \mathrm{C}$. On the other hand, when the amount of coal gangue added was as high as $50 \mathrm{wt} . \%$, the bulk density (C5) was significantly reduced. Bulk densities observed for $\mathrm{C} 3, \mathrm{C} 4$ and $\mathrm{C} 5$ sintered at $1400{ }^{\circ} \mathrm{C}$ were $1.389 \mathrm{~g} \cdot \mathrm{cm}^{-3}, 1.427 \mathrm{~g} \cdot \mathrm{cm}^{-3}$ and $1.357 \mathrm{~g} \cdot \mathrm{cm}^{-3}$, respectively.

In Figure $2 b$, the apparent density first gradually increased and then decreased with increasing sintering temperature. This could be attributed to the generation of liquid phase with increasing temperature, which promoted the densification. The apparent density of $\mathrm{C} 1$ was obviously higher, while the apparent density of $\mathrm{C} 5$ was lower than that of other samples. The apparent density

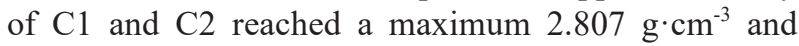
$2.791{\mathrm{~g} \cdot \mathrm{cm}^{-3}}^{-3}$, respectively, for a sintering temperature of $1400{ }^{\circ} \mathrm{C}$, while the apparent densities of the other three samples $\left(2.758 \mathrm{~g} \cdot \mathrm{cm}^{-3}, 2.729 \mathrm{~g} \cdot \mathrm{cm}^{-3}\right.$ and $2.679 \mathrm{~g} \cdot \mathrm{cm}^{-3}$, for $\mathrm{C} 3, \mathrm{C} 4$ and $\mathrm{C} 5$, respectively) reached the maximum for a sintering temperature of $1350{ }^{\circ} \mathrm{C}$. The apparent density of $\mathrm{C} 3$ and $\mathrm{C} 4$ remained more or less constant as the proppants were sintered between 1300 and $1400{ }^{\circ} \mathrm{C}$. The apparent density of $\mathrm{C} 5$ was much lower than that of the other samples, obviously because of the high addition of coal gangue.

The breakage ratios of the proppants under $35 \mathrm{MPa}$ closed pressure is shown in Figure 3, while the inset shows the breakage ratio under $52 \mathrm{MPa}$ closed pressure. As shown in Figure 3, the breakage ratio of the proppants gradually decreases with increasing sintering temperature, obviously due to the denser structure formed by sintering at higher temperature. However, for

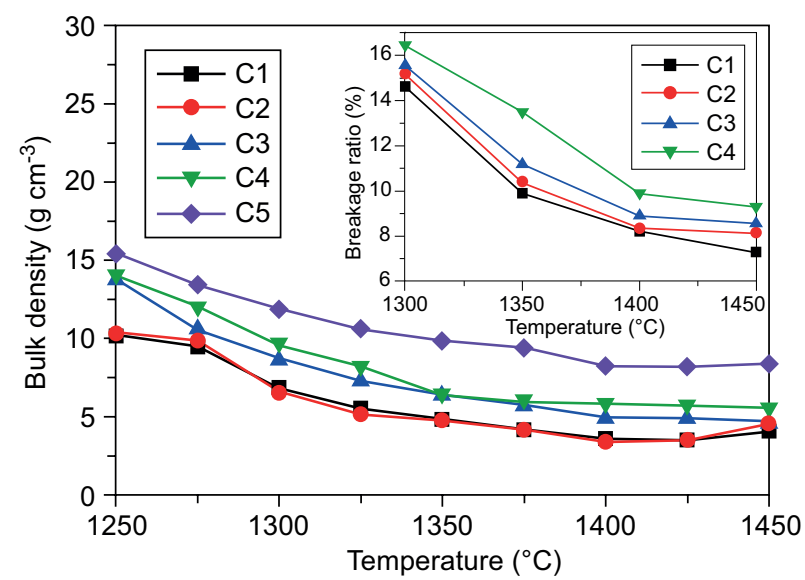

Figure 3. Breakage ratio of the proppants under $35 \mathrm{MPa}$ closed pressure (or $52 \mathrm{MPa}$ in the inset) as a function of the sintering temperature. 
sintering temperatures higher than $1400{ }^{\circ} \mathrm{C}$ the breakage ratio does not change any more. The breakage ratios of $\mathrm{C} 1$ and $\mathrm{C} 2$ are very close (lower than $7 \%$ under $35 \mathrm{MPa}$ closed pressure for sintering temperatures above $1300{ }^{\circ} \mathrm{C}$ ). When adding more coal gangue, the breakage ratio gradually increases. The breakage ratios (for $35 \mathrm{MPa}$ ) of $\mathrm{C} 3$ and $\mathrm{C} 4$ were $8.73 \%$ and $9.50 \%$, respectively, after sintering at $1300{ }^{\circ} \mathrm{C}$, but $6.42 \%$ and $6.36 \%$, respectively, after sintering at $1350{ }^{\circ} \mathrm{C}$. The breakage ratio (for $35 \mathrm{MPa}$ ) of C5 was $9.82 \%$ after sintering at $1350{ }^{\circ} \mathrm{C}$ and $8.19 \%$ after sintering at $1400{ }^{\circ} \mathrm{C}$. The inset in Figure 3, shows the breakage ratios under $52 \mathrm{MPa}$ closed pressure. The breakage ratios observed for $\mathrm{C} 1, \mathrm{C} 2, \mathrm{C} 3$ and $\mathrm{C} 4$ under $52 \mathrm{MPa}$ were $8.22 \%, 8.36 \%, 8.89 \%$ and $9.87 \%$, respectively. The breakage ratio of $\mathrm{C} 4$ exceeded the standard requirement. Although adding coal gangue can further reduce the preparation cost, adding too much gangue will increase the sintering temperature and the breakage ratio will be too high. Therefore, the suitable amount of coal gangue is $30-40$ wt. $\%$.

In short, in order to meet the requirements of the Chinese Petroleum and Gas Industry Standard SY/T 5108-2006 (breakage ratio $<9 \%$, when the proppants are applied to $35 \mathrm{MPa}$ closed pressure), considering the sintering temperature and raw material cost, $30 \mathrm{wt} . \%$ of coal gangue could be added to prepare the proppants at $1300{ }^{\circ} \mathrm{C}$, while 40 wt. $\%$ of coal gangue could be added if the sintering temperature is increased to $1350{ }^{\circ} \mathrm{C}$. The greater the amount of coal gangue added, the higher the sintering temperature. In proppants suitable for $52 \mathrm{MPa}$ closed pressure, maximally $30 \mathrm{wt}$. \% of coal gangue could be added to prepare the proppants at $1400{ }^{\circ} \mathrm{C}$.

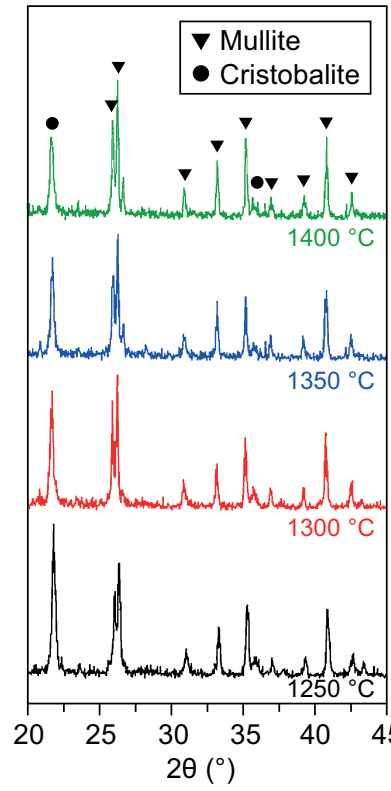

a)

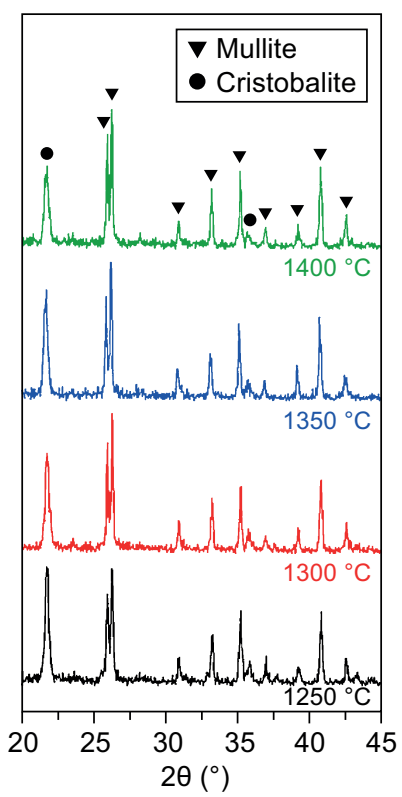

b)
Figure 4. XRD patterns of: a) $\mathrm{C} 3$ and b) $\mathrm{C} 4$ sintered at different temperatures.
Figure $4 \mathrm{a}$ and $4 \mathrm{~b}$ present XRD patterns of C3 and C4 sintered at different temperatures. The pattern are very similar, and their main diffraction peaks could be attributed to mullite $\left(\mathrm{Al}_{6} \mathrm{Si}_{2} \mathrm{O}_{13}, J C P D S: 15-0776\right)$ and cristobalite $\left(\mathrm{SiO}_{2}, \mathrm{JCPDS}\right.$ : 27-0605). Mullite resulted from the decomposition of the clay minerals (mainly kaolinite present in the flint clay), and cristobalite was formed from the transformation of quartz or via recrystallization from the (originally amorphous) silica released from the clay minerals. From Figure 4, when the samples (C3 and $\mathrm{C} 4$ ) were sintered at $1250{ }^{\circ} \mathrm{C}$, the diffraction peaks of mullite phase were distinct and sharp, as expected for these temperatures, which are much higher than the temperatures of the decomposition of clay minerals and the subsequent transformation reactions. The diffraction peak intensity of cristobalite was lowest for the samples sintered at $1400{ }^{\circ} \mathrm{C}$. At the same time, the diffraction peak intensity of mullite reached the highest value for the samples sintered at $1400^{\circ} \mathrm{C}$. Thus, with increasing sintering temperature, the diffraction peak intensity of cristobalite gradually decreases, while that of mullite phase gradually increases, indicating the formation of secondary mullite (by reprecipitation from the glass melt) or the dissolution of cristobalite in the glass melt.

Figure 5 shows SEM images of fracture section of $\mathrm{C} 3$ and $\mathrm{C} 4$ sintered at different temperatures. It is clear from Figure $5 \mathrm{a}$ that the proppants $(\mathrm{C} 4)$ prepared by adding 40 wt. $\%$ coal gangue at $1350{ }^{\circ} \mathrm{C}$ had a denser microstructure. The large amount of interlaced rodshaped mullite grains, with interdispersed cristobalite grains, are expected to improve the strength of the proppants. Moreover, less pores are present, which improves the performance of the samples, as shown in Figure 4. Figure 5b and 5c are SEM images of C3 and C4 sintered at $1400{ }^{\circ} \mathrm{C}$. In comparison, the proppants (C4) sintered at $1400{ }^{\circ} \mathrm{C}$ possess a more compact structure than those sintered at $1350{ }^{\circ} \mathrm{C}$, owing to the

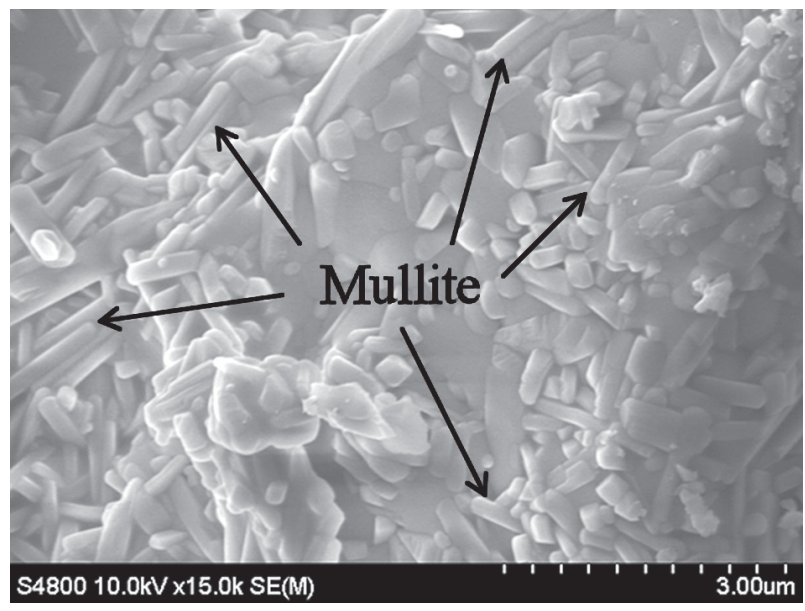

a) $\mathrm{C} 4$ at $1350{ }^{\circ} \mathrm{C}$

Figure 5. SEM images of fracture sections of: a) $\mathrm{C} 4$ at $1350{ }^{\circ} \mathrm{C}$. (Continue on next page) 


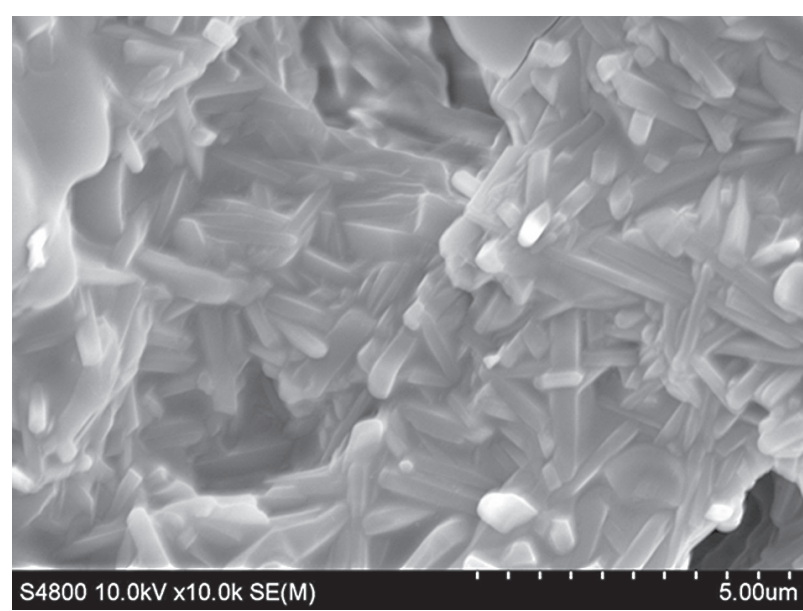

b) $\mathrm{C} 3$ at $1400^{\circ} \mathrm{C}$

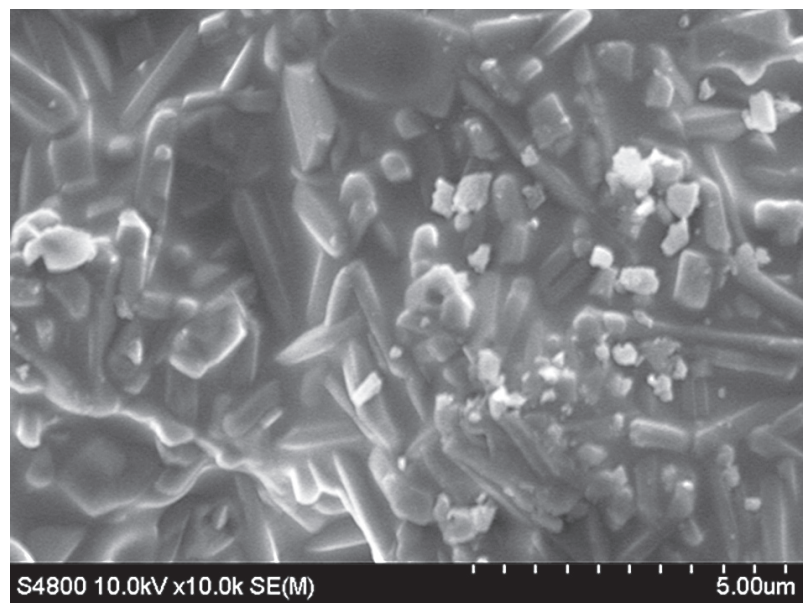

c) $\mathrm{C} 4$ at $1400{ }^{\circ} \mathrm{C}$

Figure 5. SEM images of fracture sections of: b) $\mathrm{C} 3$ and c) $\mathrm{C} 4$ at $1400{ }^{\circ} \mathrm{C}$

obvious vitreous phase. In Figure $5 \mathrm{~b}$ and $5 \mathrm{c}$, mullite grains can be seen to have grown, and the boundaries between mullite grains became diffuse, probably due to vitreous phase generated at high temperature. The content of vitreous phase in $\mathrm{C} 4$ (Figure 5c) was higher than in C3 (Figure 5b), mainly due to the higher amount of coal gangue. Furthermore, the content of rod-shaped mullite was obviously higher in $\mathrm{C} 3$ than in $\mathrm{C} 4$, which is why better performance is expected for $\mathrm{C} 3$ than for C4. This observation is consistent with the performance results shown in Figure 3, because mullite is responsible for toughening in the structure. Sample C3 exhibited a small amount of closed pores, see Figure $5 \mathrm{~b}$, while no pores were observed in sample $\mathrm{C} 4$, which is also related to the higher content of coal gangue.

\section{CONCLUSIONS}

Low-density ceramic proppants for coal bed methane wells were successfully fabricated from flint clay and solid waste coal gangue. The density of the proppants was significantly reduced by flint clay instead of bauxite, and the preparation cost was greatly decreased by the addition of coal gangue. XRD patterns and SEM images suggested that the proppants were mainly composed of rod-shaped mullite and granular cristobalite. Proppants for application at $35 \mathrm{MPa}$ closed pressure could be sintered at $1300{ }^{\circ} \mathrm{C}$ by adding $30 \mathrm{wt} . \%$ coal gangue, and sintered at $1350{ }^{\circ} \mathrm{C}$ by adding $40 \mathrm{wt} . \%$ coal gangue. Bulk densities were $1.252 \mathrm{~g} \cdot \mathrm{cm}^{-3}$ and $1.291 \mathrm{~g} \cdot \mathrm{cm}^{-3}$, and breakage ratios $8.7 \%$ and $6.4 \%$, respectively. Proppants, suitable for $52 \mathrm{MPa}$ closed pressure could be sintered at $1400{ }^{\circ} \mathrm{C}$ by adding $30 \mathrm{wt} . \%$ coal gangue, resulting in a bulk density of $1.389 \mathrm{~g} \cdot \mathrm{cm}^{-3}$ and a breakage ratio of $8.9 \%$. These low-density ceramic proppants met the requirements of ideal fracturing materials. Thus it has been confirmed that it is feasible to prepare proppants using flint clay and coal gangue, and these proppants could become ideal candidates for fracturing proppants in future applications of coal bed methane wells.

\section{Acknowledgements}

This work was supported by the Shanxi Province Science and Technology Major Special Project (Grant No. 20181101001), Talents Training Project of Shanxi Graduate Joint Training Base (Grant No. 2018JD34), Fund for Shanxi Key Subjects Construction and the Collaborative Innovation Center of Shanxi Key Basic Materials.

\section{REFERENCES}

1. Liang F., Sayed M., Al-Muntasheri G.A., Chang F.F., Li L. (2016): A comprehensive review on proppant technologies. Petroleum, 2(01), 26-39. doi: 10.1016/j.petlm.2015.11.001

2. Fu L.P., Zhang G.C., Ge J.J. Liao K.L., Jiang P., Pei H.H., Li X.Q. (2016): Surface modified proppants used for porppant flowback control in hydraulic fracturing. Colloids and Surfaces A: Physicochemical and Engineering Aspects, 507, 18-25. doi: 10.1016/j.colsurfa.2016.07.039

3. Wu T.T., Wu B.L. (2012): Corrosion resistance of ceramic proppant in $\mathrm{BaO}-\mathrm{CaO}-\mathrm{P}_{2} \mathrm{O}_{5}-\mathrm{Al}_{2} \mathrm{O}_{3}$ system. Corrosion Science, 63, 399-403. doi: 10.1016/j.corsci.2012.06.025

4. Zhao J.Z., Liu Z.L., Li Y.M. (2015): Preparation and characterization of low-density mullite-based ceramic proppant by a dynamic sintering method. Materials Letters, 152, 72-75. doi: 10.1016/j.matlet.2015.03.060

5. Wu T.T., Zhou J., Wu B.L. (2016): Effect of $\mathrm{Sc}_{2} \mathrm{O}_{3}$ on the acid resistance of alumina ceramic. Materials Letters, 175, 82-85. doi: 10.1016/j.matlet.2016.04.017

6. Hao J.Y., Ma H.Q., Feng X., Gao Y.F., Wang K.Y., Tian Y.M., Chai Y.S. (2018): Microstructure and fracture mechanism of low density ceramic proppants. Materials Letters, 213, 92-94. doi: 10.1016/j.matlet.2017.11.021

7. Hellmann J.R., Scheetz B.E., Luscher W.G., Hartwich D.G., Koseski R.P. (2014): Proppants for shale gas and oil recovery: Engineering ceramics for stimulation of unconventional energy resources. American Ceramic Society Bulletin, 93, 28-35. 
8. Wu T.T., Zhou J., Wu B.L. (2015): Effect of $\mathrm{TiO}_{2}$ content on the acid resistance of a ceramic proppant. Corrosion Science, 98, 716-724. doi: 10.1016/j.corsci.2015.06.012

9. Hammond P.S. (1995): Settling and slumping in a Newtonian slurry, and implications for proppant placement during hydraulic fracturing of gas wells. Chemical Engineering Science, 50, 3247-3260. doi: 10.1016/0009-2509 (95)00152-U

10. Fang Q., Sidky P.S., Hocking M.G. (1997): The effect of corrosion and erosion on ceramic materials. Corrosion Science, 39, 511-527. doi: 10.1016/S0010-938X(97) 86100-8

11. Hao J.Y., Ma H.Q., Feng X., Gao Y.F., Wang K.Y., Tian Y.M. (2017): Low-temperature sintering of ceramic proppants by adding solid wastes. International Journal of Applied Ceramic Technology, 15, 563-568. doi: 10.1111/ijac.12818
12. Mocciaro A., Lombardi M.B., Scian A.N. (2018): Effect of raw material milling on ceramic proppants properties. Applied Clay Science, 153, 90-94. doi: 10.1016/j.clay.2017. 12.009

13. Kulkarni M.C., Ochoa O.O. (2012): Mechanics of light weight proppants: A discrete approach. Composites Science and Technology, 72(8), 879-885. doi: 10.1016/j.compscitech. 2012.02.017

14. Ma X.X., Tian Y.M., Zhou Y., Wang K.Y., Chai Y.S., Li Z.G. (2016): Sintering temperature dependence of lowcost, low-density ceramic proppant with high breakage resistance. Materials Letters, 180, 127-129. doi: 10.1016/j. matlet.2016.04.080

15. Qian T.T., Li J.H. (2015): Synthesis of Na-A zeolite from coal gangue with the in-situ crystallization technique. Advanced Powder Technology, 26 98-104. doi: 10.1016/j. apt.2014.08.010 